Trakya Üniversitesi

Eğitim Fakültesi Dergisi

Cilt 8, Say1 2

Ocak 2018 390-409

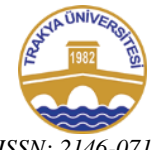

ISSN : 2146-071X
Trakya University

Journal of Education Faculty

Volume 8, Issue 2

January 2018, 390-409

Doi: $10.24315 /$ trkefd. 364050

Geliș Tarihi: 13.11.2016

Yayına Kabul Tarihi: 27.07.2017

\title{
Bilim Şenliklerinin Ortaokul 6. Sınıf Öğrencilerinin Problem Çözme Becerilerine Etkisi ${ }^{1}$
}

\section{The Effect of Science Fairs on the $6^{\text {th }}$ Grade Students' Problem Solving Skills}

\author{
Halil İbrahim YILDIRIM²
}

\begin{abstract}
Öz: Bu araştırma, bilim şenliklerinin 6. sınıf öğrencilerinin problem çözme beceri düzeylerine etkisini incelemek amacıyla yapılmıştır. Araştırmada yarı deneysel yöntem, kontrol ve deney gruplu deneysel desen kullanılmıştır. Araştırma 2014-2015 eğitim-öğretim yılı ikinci döneminde 6. sınıf öğrencileri üzerinde uygulanmış ve 15 hafta sürmüştür. Verilerin toplanmasında "Problem Çözme Beceri Ölçeği" kullanılmıştır. Araştırmanın sonunda deney grubundaki öğrencilerin problem çözme beceri düzeylerinin anlamlı seviyede arttığı belirlenmiştir. Ayrıca araştırma tamamlandıktan üç ay sonra bu artışın korunduğu görülmüştür. $\mathrm{Bu}$ sonuçlara dayanarak, ülkemizdeki okullarda bilim şenlikleri gibi etkinliklerin yaygınlaştırılmasının ve öğrencilerin bu tür etkinliklere katılımlarının teşvik edilmesinin yararlı olacağı söylenebilir.

Anahtar sözcükler: Bilim şenliği, problem çözme becerisi, fen ögretimi, informal ögrenme ortamlarl
\end{abstract}

\begin{abstract}
The aim of the present research is to investigate the effect of science fairs on the 6th grade students' problem solving skills. A quasiexperimental method and an experimental pattern with control and experiment groups is used in the research. The research was applied on the $6^{\text {th }}$ grade students during 2014-2015 educational year II. semester and lasted 15 weeks. The Scale of Problem Solving Skill was used to collect the data. At the end of the research, an increase was determined 6th grade secondary school students' problem solving skills. Three months after research it was observed that the increase of students' problem solving skills has been preserved. Based on these results, it is recommended to disseminate activities such as science fairs in schools in our country and encourage students to participate in such activities.
\end{abstract}

Keywords: Science fair, problem solving skill, science instruction, informal learning environments

\footnotetext{
1 Bu çalışma 21-24 Nisan 2016 tarihinde Antalya'da düzenlenen 25. Ulusal Eğitim Bilimleri Kongresi'nde sözlü bildiri olarak sunulmuştur.

2 Yrd. Doç. Dr.., Gazi Üniversitesi , e-posta: halily@gazi.edu.tr
} 


\section{GíRiş}

Öğrencilerde problem çözme becerisinin geliştirilmesi, tüm eğitim kurumlarının en önemli amaçlarından biridir. Bireylerin toplumsal yaşama ve değişime uyum sağlaması, başarılı ve bağımsız olması için problem çözme becerisi ile donanması gerekmektedir (Kalayc1, 2001). Öğretim programlar1 incelendiğinde 2004 Fen ve Teknoloji Dersi Öğretim Programı'nda problem çözme becerisi öğrencilerde geliştirilmesi amaçlanan beceriler içinde yer almıştır (MEB, 2006). Ayrıca 2013 yılında güncellenen Fen Bilimleri Dersi Öğretim Programı'nda problem çözebilen, bir başka deyişle problem çözme becerisine sahip fen okuryazar bireylerin yetiştirilmesi vurgulanmaktadır (MEB, 2013). Her iki öğretim programında da öğrencilerin problem çözme becerilerinin geliştirilmesinin, önemli bir amaç olarak yer almakta olduğu görülmektedir.

Problem çözme becerisi belli bir amaca ulaşmak için, karşılaşılan güçlükleri ortadan kaldırmaya yönelik olarak birey tarafindan gösterilen çözüm üretme becerisidir (Yıldırım, 2009). Problem çözme kavram olarak çok eskiden bu yana kullanılmasına rağmen, ilk olarak Amerikalı eğitimci John Dewey tarafından sistemleştirilmiştir. Problem çözme genellikle bir soruya cevap vermenin planını yapma, zorlu bir göreve tatmin edici bir durum veya karşıllık sunma, bir çözüm önerme veya ilgi göstermedir. Problem çözmede kullanılabilecek çalışmalar şunlar olabilir: Kaynakları tarama, hazır çözümleri kontrol etme, uzman görüşü alma, hemen uygulama, ekip oluşturma vb. (Aslan, 2002).

Problem çözme, hem konu alan bilgisini hem de duruma uygun bilişsel stratejileri seçip kullanmayı gerektiren bir etkinliktir. Ayrıca problem çözmede önemli olan nokta, amaca götürecek aracı bulup işe koşmaktır (Senemoğlu, 2001). Problem çözme, bir sonuç değil bir süreçtir. Kneeland'e (2001) göre problem çözme sürecinin basamakları problemin farkına varma, gerekli bilgilerin toplanması, problemin temeline inme, çözüm yollarının araştırılması ve bulunması, en uygun çözüm yolunun tespiti, problemi çözme şeklindedir.

Öğrencilerin problem çözme ve bilimsel süreç becerileri gibi öğrenme çıktılarında gelişim sağlamanın yolu, problem çözme basamaklarını gerçekleştirebileceği, bilimsel yöntemi uygulayabileceği ve bilimsel süreç becerilerini kullanabileceği öğrenme-öğretme süreçlerini ve ortamlarını oluşturup, işler kılmaktır. Bunun gerçekleştirilmesinde kuşkusuz bilim şenlikleri (fen, matematik, sosyal bilimler şenlikleri vb.), buluş şenlikleri, bilim-proje fuarları ve proje yarışmaları gibi etkinlikler oldukça önemli bir role sahiptir. Bilim şenlikleri de öğrencilerin problem çözme ve bilimsel süreç becerilerini olumlu yönde geliştirerek öğrenme çıktıları üzerinde gelişim sağlayabilecek bilimsel bir etkinliktir (Yıldırım ve Şensoy, 2014). Ayrıca bilim şenlikleri öğrencilerin bilimsel düşünme ve bilimsel süreç becerilerini en uygun şekilde kullanabildiği, ilgi duyduğu alanlarda üretebildiği ve ürettiğinde de "benim eserim" duygusunu yaşayarak özgüvenini arttırdığı organizasyonlardır (Camcı, 2008).

Bilim şenliği ve proje yarışmaları, öğrenenin bilimsel araştırma sürecine uygulamalı olarak doğrudan katılmasına olanak veren, öğrenci projelerinin sunulduğu ve paylaşıldığı organizasyonlardır (Korkmaz, 2004). Bu projeler 
öğrencilerin derslerde öğrenmiş oldukları bilgileri uygulamalarına olanak sağlar. Birçok öğretmen bilim şenliklerinin öğrenciler için faydalı olduğunu düşünmektedir. Bilim şenliklerinin öğrencilerin yaratıcılıklarını geliştirdiğini, kendi projelerini seçerek bağımsız araştırma yapmalarına firsat sağladığını ve bilime karşı ilgilerini artırdığını belirtmektedirler (Bunderson, 1996). Bilim şenlikleri öğrenciler için bilim insanlarının nasıl çalıştıklarını anlamaları için bir model oluşturmaktadır. Bu projeler öğrencilerin derslerde öğrenmiş oldukları bilgileri uygulamalarına olanak sağlar (Young, 2000). Bilim şenliklerinin öğrencilere birçok özelliği (iletişim kurma, işbirlikli çalışma, özgüven sağlama, planlı çalışma, kendini ifade edebilme vb.) öğretici olmasının yanında en önemli özelliği, öğrencilere bilimsel araştırma yöntemini kullanmalarını, bilime ve bilim insanına ilgilerini artırmada etkili olmasıdır (Camc1, 2008).

Perry (1995) bilim şenliklerinin, öğrencilerin bilime olan ilgilerini arttırmakta, öğrencileri araştırma yapabilmeleri için geliştirmekte, öğrencilerin tamamladıkları projeleri yayımlama ve çalışmalarını paylaşarak gelişimlerini sağlamakta olduğunu ifade etmektedir. Ayrıca bilim şenlikleri, proje yarışmaları, buluş şenlikleri, bilim ve teknoloji müzeleri, hayvanat bahçeleri ve doğa gezilerinin informal fen öğretiminin özellikleri göz önüne alındığında, informal öğrenme ortamları olduğu söylenebilir.

Bazı araştırmalar informal öğrenme ortamlarının öğrencilerin bilişsel ve duyuşsal alanlarına önemli etkilerinin olduğunu (Knapp, 2000) ve informal öğrenme ortamlarının (okul dışı öğrenme ortamlarının) ve bu ortamlarda gerçekleştirilen etkinliklerin sayısının arttırılması gerektiğini ortaya koymuştur (Çavuş, Umdu Topsakal ve Öztuna Kaplan, 2013; Rapp, 2005). İnformal fen eğitimi "bireyin hayatında doğal olarak ortaya çıkan ve deneyimleri sonucunda oluşan öğrenmeleri içerir (Türkmen, 2010). İnformal fen öğretiminin özellikleri Hofstein ve Rosenfeld (1996) tarafından gönüllü, yapılandırılmamış, sıralı değil, ölçme yok, değerlendirmeye dayalı değil, sınırlandırılmamış, yönlendiren öğrenci, öğrenen merkezli, okul dışında gerçekleştirilen, program temelli olmayan, pek çok plansız öğrenme çıktıları bulunan, az sayıda direk olarak ölçülebilen öğrenme çıktıları bulunan, sosyal çalışma, yönetilmeyen ya da öğrenenin yönettiği şeklinde belirtilmiştir. Bu bağlamda bilim şenlikleri, proje yarışmaları, buluş şenlikleri, bilim ve teknoloji müzeleri, hayvanat bahçeleri ve doğa-alan gezilerinin Hofstein ve Rosenfeld (1996), Türkmen (2010) tarafindan belirtilen informal fen öğretiminin özelliklerini sağladığı söylenebilir. Buna dayanarak bu çalışmada bilim şenliklerinin yanı sıra informal öğrenme ortamlarına da yer verilmiş ve informal öğrenme ortamlarına yönelik literatür de incelenmiştir.

Bilim şenliklerinin öğrencilerin duyuşsal özellikleri üzerindeki etkisine yönelik çalışmalar bilim şenliklerinin derse yönelik tutumlarının gelişimi ve derse yönelik ilgileri üzerinde olumlu etkileri olduğu (Şahin, 2012), (Yıldırım ve Şensoy, 2014), öğrencilerin proje fuarlarılya ilgili olarak olumlu görüş ve düşünceler geliştirdikleri (Karadeniz ve Ata, 2013), bilim şenliğine katılan öğrencilerin daha çok bilimin doğası ve bilimsel süreçle ilgilenirken, bilim şenliğine katılmayan öğrencilerin daha çok günlük hayatta doğrudan gözlemlenen olaylarla ilgili olduğu (Camcı, 2008) sonuçlarını ortaya koymuştur. 
İnformal öğrenme ortamlarına yönelik bazı çalışmalarda ise informal öğrenme ortamlarının öğrencilerin başarılarında olumlu yönde artı̧ sağladığı (Altıntaş, 2014), öğrencilerin konuyu anlama ve konuyu günlük hayatla ilişkilendirme düzeylerini olumlu yönde etkilediği (Ertaş, Şen ve Parmaksızoğlu, 2011), öğretmenlere göre öğrencilerin ilgi, istek ve meraklarını attırmada etkili olduğu (Tatar ve Bağrıyanık, 2012), öğrencilerin çevre bilinci kazanmalarında olumlu yönde etkisinin olduğu ve bu sebeple okul dışı öğrenme ortamlarının ve bu ortamlarda gerçekleştirilen etkinliklerin sayısının arttırılması gerektiği (Çavuş, Umdu Topsakal ve Öztuna Kaplan, 2013), öğrencilerin bir günlük alan gezisi sonrasında tutumlarının olumlu yönde olduğu (Nadelson ve Jordan, 2012), öğrencilerin fen konularına yönelik ilgilerini ve akademik başarılarını anlamlı bir şekilde geliştirmede ve devamının sağlanmasında önemli bir etkiye sahip olduğu (Bozdoğan, 2007) sonuçlarına ulaşılmıştır.

İnformal öğrenme ortamları açısından Fen Bilimleri Ders Programı incelenecek olursa, 2013 Fen Bilimleri Dersi Öğretim Programı'nda araştırmasorgulamaya dayalı öğrenme yaklaşımı temel alınmıştır. Fen Bilimleri Dersi Öğretim Programı'na göre derslerin planlanması ve uygulanmasında öğrencinin aktif, ögretmenin ise rehber ve yönlendirici olacağı öğrenme ortamları (problem, proje, argümantasyon, işbirliğine dayalı öğrenme vb.) temel alınmıştır. Öğrencilerin fen bilimleri alanındaki bilgiyi anlamlı ve kalıcı olarak öğrenebilmeleri için sınıf içi ve okul dışı öğrenme ortamları, araştırmasorgulamaya dayalı öğrenme stratejisine göre tasarlanır. Bu bağlamda informal öğrenme ortamlarından da (bilim, sanat ve arkeoloji müzeleri, hayvanat bahçesi, doğal ortamlar vb.) faydalanılır (MEB, 2013). Bilim şenliklerinin de öğrencinin aktif, öğretmenin ise rehber ve yönlendirici olduğu, araştırma-sorgulamaya dayalı öğrenme stratejisine göre tasarlanan okul dışı öğrenme ortamı olduğu söylenebilir. Bu bağlamda bilim şenliklerinin Fen Bilimleri Öğretim Programı'nda vurgulanan informal öğrenme ortamlarından faydalanılması gerekliliğini sağladığı ifade edilebilir.

Literatür incelendiğinde ülkemizde bilim şenliklerinin öğrenme ürünleri üzerindeki etkisine yönelik çalışmaların az sayıda olduğu söylenebilir. Bu bağlamda bilim şenlikleri gibi etkinliklerin öğrencilerin problem çözme becerisi gibi öğrenme çıtılarının gelişimi üzerindeki etkisinin belirlenmesine yönelik çalışmaların literatüre katkı sağlayacağ 1 düşünülmektedir. Buna ilaveten öğrencilerin problem çözme beceri düzeylerini etkileyen değişkenlerin belirlenmesine yönelik çalışmaların; problem çözme beceri düzeylerinin arttırılması, fen öğretim programının amaçlarına ulaşması ve literatüre katkı sağlaması açısından önemli ve gerekli olduğu söylenebilir. Bu gerekçelere dayanarak bu araştırma bilim şenliklerinin ortaokul altıncı sınıf öğrencilerinin problem çözme beceri düzeylerine etkisini incelemek amacıyla yapılmıştır. 


\section{YÖNTEM}

\subsection{Araştırmanın Tasarımı}

Araştırmada yarı deneysel yöntem ve ön test-son test kontrol gruplu deneysel desen kullanılmıştır (Linn ve Gronlund, 2000). Araştırmada kontrol ve deney grubundaki öğrencilerin seçiminde seçkisizlik ilkesi ya da kura ile ögrencilerin deney ve kontrol grubuna atanması gerçekleştirilmediği ve hazır şubeler kullanıldığı için araştırma yarı deneyseldir (Büyüköztürk, Kılıç Çakmak, Akgün, Karadeniz ve Demirel, 2016).

\subsection{Araştırmanın Çalışma Grubu}

Araştırmanın çalışma grubunu 2014-2015 eğitim-öğretim yılı ikinci döneminde Ankara'daki bir devlet ortaokulunda öğrenim gören altıncı sınıf öğrencileri oluşturmuştur. Araştırmada çalışılacak dört sınıftan hangi ikisinin deney, hangi ikisinin kontrol grubu olacağına seçkisiz atama yöntemi ile karar verilmiş olup, iki sınıf kontrol grubu, diğer iki sınıf ise deney grubu olarak belirlenmiştir.

Araştırmanın çalışma grubunda; kontrol grubunda 45, deney grubunda ise 46 öğrenci olmak üzere toplam 91 öğrenci bulunmaktadır. Deney grubuna iki tane şube alınmasının nedeni bilim şenliğindeki etkinlik sayısını arttırmaktır. Deney grubu iki şube seçildiği için denkliğin sağlanması açısından kontrol grubu da iki şube olarak seçilmiştir (Büyüköztürk vd., 2016).

\subsection{Araştırmanın Uygulanması}

15 hafta süren araştırma, 2014-2015 eğitim-öğretim yılında Ankara'daki bir devlet ortaokulunda öğrenim gören altıncı sınıf öğrencileri üzerinde yürütülmüştür. Deney grubundaki öğrencilerin araştırmaya katılımında gönüllü katılım esas alınmış ve bütün öğrenciler deney grubuna gönüllü olarak katılmıştır. Araştırmanın uygulama basamağı, kontrol ve deney grubunda fen bilimleri dersinde aynı öğretmen tarafından gerçekleştirilmiştir. Kontrol grubunda deneysel bir işlem uygulanmamış, Fen Bilimleri Dersi Öğretim Programına uygun ve öğrenci merkezli olarak öğretim yapılmıştır.

Deney grubunda da kontrol grubundaki öğretime paralel olarak öğretim yapılırken, her hafta bir dersin 15-20 dakikalık bölümünde bilim şenlikleri çalışmalarına yer verilmiştir. Öncelikle deney grubu öğrencilerine bilim şenlikleri, bilimsel yöntem, problem çözme basamakları, proje-araştırma basamakları, proje günlükleri hakkında sunumlar ile bilgilendirme yapılmış ve bunlara ilişkin örnek çalışmalar gösterilmiştir. Öğrencilerden iki kişilik gruplar oluşturulmuştur. Öğrencilerden bilim şenliği için ilgilerini çeken fen konularında bir problem belirlemeleri, bilimsel yöntemi kullanarak bu problemi çözebilmek için bir etkinlik tasarlamaları ve araştırma yapmaları istenilmiştir. Öğrencilerin araştırmaları sonucunda ulaştıkları etkinliklerden ortaokul öğrencilerinin seviyesine uygun olanlar öğretmen rehberliğinde seçilerek, öğrenciler tarafından bilim şenliği etkinlikleri hazırlanmıştır. Öğrenciler bu etkinlikler için öğretmen rehberliğinde poster ve sunumlarını hazırlamıştır. 15 haftalık bir hazırlık sonucunda bilim şenliğinin açılışı yapılarak iki gün süresince öğrenciler tarafından ziyaretçilere etkinlikler sunulmuştur. 


\subsection{Veri Toplama Araçları}

$\mathrm{Bu}$ araştırmada, ortaokul öğrencilerinin problem çözme beceri düzeyini belirleyebilmek amacıyla Yaman (2003) tarafından geliştirilen "Problem Çözme Beceri Ölçeği”" kullanılmıştır. "Tamamen Katılıyorum” dan "Hiç Katılmıyorum” a kadar 5'li likert dereceleme biçiminde ,82 güvenilirlikte geliştirilen bu ölçek 30 maddeden oluşmaktadır. Ölçek bu araştırmada ön test, son test ve son test uygulandıktan üç ay sonra izleme testi olarak uygulanmıştır. Ölçeğin bu araştırma için Cronbach Alpha $(\alpha)$ güvenirlik katsayısı ,88 olarak hesaplanmıştır. Ölçeğin uygulanmasından elde edilen verilerin analizinde, maddelerde yer alan her bir olumlu ifade için "Tamamen Katılıyorum" ifadesi 5 puan, "Katılıyorum" ifadesi 4 puan, "Kısmen Katıliyorum" ifadesi 3 puan, "Katılmiyorum" ifadesi 2 puan, "Hiç Katılmıyorum" ifadesi 1 puan olarak puanlanmıştır. Maddelerdeki olumsuz ifadelerin puanlanmasında ise, yukarıdaki puanlamanın tersi işlemler yapılmıştır. Ölçekten alınan toplam puan, ölçekteki madde sayısına bölünerek, her bir öğrenci için problem çözme beceri puanı hesaplanmıştır. Buna göre ölçekten alınabilecek en düşük puan 1, en yüksek puan ise 5 'dir.

Ölçek; ortaokul altıncı sınıf öğrencilerinin araştırmanın başındaki problem çözme beceri seviyelerini belirleyebilmek için ön test, deneysel işlemin etkisini belirleyebilmek için araştırmanın sonunda son test ve araştırma sona erdikten üç ay sonra ise izleme testi olarak kullanılmıştır. Testten alınan toplam puan, bireyin problem çözme beceri düzeyini göstermektedir.

\subsection{Verilerin Analizi}

Araştırmanın nicel verilerinin analizinde Microsoft Excel 2010 elektronik tablo programı ve SPSS 22 istatistik analiz programı kullanılmıştır. Öğrencilerin ölçeğe verdikleri yanıtların genel dağılımlarının belirlenmesi ve nicel verilerin normal dağılım gösterip göstermediğinin araştırılmasında betimsel istatistik tekniklerinden (mod, medyan, aritmetik ortalama, standart sapma) yararlanılmıştır. Ayrıca ölçek puanlarına ait merkezi eğilim (ortalama, mod ve medyan) ve merkezi dağılım (standart sapma, çarpıklık ve basıklık) değerleri kullanılmıştır. Araştırmada kontrol ve deney grubuna ait puanların ortalamaları arasında anlamlı düzeyde fark olup olmadığını belirleyebilmek için "Bağımsız Gruplar İçin t-Testi”" analizi uygulanmıştır. Kontrol ve deney grubunun kendi içinde, araştırma sürecinin başındaki ön test ile araştırmanın sonundaki son test ve araştırma tamamlandıktan üç ay sonrasındaki izleme testi puan ortalamaları arasında anlamlı düzeyde bir fark olup olmadığını belirleyebilmek için, "Tekrarlı Ölçümler İçin Tek Faktörlü ANOVA” kullanılmıştır. Tüm analizler .05 anlamlılık düzeyinde değerlendirilmiştir (Büyüköztürk, 2016). 


\section{BULGULAR}

Öğrencilerin kontrol ve deney grubuna dağılımına ilişkin betimsel istatistik sonuçları Tablo 1'de görülmektedir.

Tablo 1. Öğrencilerin kontrol ve deney grubuna dağılımına ilişkin betimsel istatistik sonuçları

\begin{tabular}{ccc}
\hline Cinsiyet & N & \% \\
\hline Kontrol & 45 & 49,45 \\
Deney & 46 & 49,55 \\
Toplam & $\mathbf{9 1}$ & $\mathbf{1 0 0 , 0 0}$ \\
\hline
\end{tabular}

Tablo 1 incelendiğinde örneklemin \% 49.45'ini kontrol grubu, \% 49.55'ini deney grubu öğrencilerinin oluşturduğu görülmektedir.

Kontrol ve deney grubundaki öğrencilerin problem çözme becerisi ön, son ve izleme testi puanları istatistiki olarak analiz edilmeden önce, ölçekten elde edilen nicel verilerin analizinde hangi istatistiksel yöntemin kullanılacağ1 araştırılarak karar verilmiştir. Nicel araştırmalarda verilerin analizinde, hem parametrik hem de non-parametrik (parametrik olmayan) istatistiksel yöntemler kullanılabilmektedir. Parametrik istatistik analiz yöntemlerinin kullanılabilmesi için araştırma sürecinde uygulanan test ve ölçeklerden elde edilen nicel verilerin normal dağılım göstermesi gerekmektedir (Sim ve Wright, 2002). Bu bağlamda problem çözme beceri ölçeğinden elde edilen verilerin analizinde kullanılacak istatistiksel yöntemin belirlenmesi için analizler yapılmış ve sonuçları Tablo 2'de verilmiştir. Tablo 2'deki bulgulara dayanarak kontrol ve deney grubundaki öğrencilerin problem çözme becerisi ön, son ve izleme testi puanlarının normal dağılım gösterip göstermediği incelenmiştir.

Tablo 2. Kontrol ve deney grubundaki öğrencilerin problem çözme becerisi ön test, son test ve izleme testine ilişkin betimsel istatistik sonuçları

\begin{tabular}{cccccrrrr}
\hline Test & Grup & N & \multicolumn{1}{c}{$\bar{x}$} & S & Medyan & Mod & Çarpıklık & Basıklık \\
\hline Ön & Kontrol & 45 & 99,13 & 14,90 & 99 & 93 & 0,31 & $-0,62$ \\
Test & Deney & 46 & 98,78 & 13,32 & 99 & 99 & 0,09 & $-0,35$ \\
\hline Son & Kontrol & 45 & 100,69 & 15,26 & 100 & 96 & 0,06 & $-1,00$ \\
Test & Deney & 46 & 113,89 & 14,21 & 114,50 & 108 & 0,14 & $-0,45$ \\
\hline İzleme & Kontrol & 45 & 98,96 & 13,51 & 98 & 93 & 0,35 & $-0,75$ \\
Testi & Deney & 46 & 111,96 & 14,54 & 112 & 105 & 0,07 & 0,10 \\
\hline
\end{tabular}

Tablo 2 incelendiğinde, kontrol grubundaki öğrencilerin problem çözme becerisi ön test puan ortalamaları, medyan ve mod değerlerinin birbirine yakın olduğu görülmektedir. Deney grubundaki öğrencilerin de ön test puan ortalamaları, medyan ve mod değerleri birbirine yakındır. Benzer şekilde hem kontrol grubunun son test puanlarına ait ortalama, medyan ve mod değerleri, hem de deney grubunun son test puanlarına ait ortalama, medyan ve mod değerleri birbirine yakındır. Buna ilaveten kontrol grubunun izleme testi puanlarına ait ortalama, medyan ve mod değerleri birbirine yakınken, aynı zamanda deney 
grubunun da izleme test puanlarına ait ortalama, medyan ve mod değerleri birbirine yakındır. Ayrıca kontrol ve deney grubu öğrencilerinin ön test, son test ve izleme testi puanlarına ait basıklık ve çarpıklık değerlerinin -1.5 ile +1.5 aralığı arasında olduğu görülmektedir.

Kontrol ve deney grubu öğrencilerinin problem çözme becerisi ön, son ve izleme testlerine ait aritmetik ortalama, medyan ve mod değerlerinin birbirine yakın olması, ön, son ve izleme testleri puanlarına ilişkin basıklık ve çarpıklık değerlerinin bulunduğu aralık (-1.5 ile +1.5 aralığı) ve hem kontrol hem de deney grubunda örneklem sayısının 30'dan büyük olması bulguları, kontrol ve deney grubuna uygulanan problem çözme becerisi ön, son ve izleme testlerinden elde edilen verilerin normal dağıldığını göstermektedir (Baykul, ve Güzeller, 2014; Kalayc1, 2016; Köklü, Büyüköztürk ve Bökeoğlu, 2006; Tabachnick ve Fidell, 2013). Bu betimsel istatistik sonuçlarına dayanarak normal dağılım gösterdiği belirlenen verilerin analizinde, parametrik testlerin kullanılmasına karar verilmiştir. Bu bağlamda kontrol ve deney gruplarının problem çözme becerisi ön, son ve izleme testi puan ortalamaları arasında anlamlı fark olup olmadığı "Bağımsız Gruplar İçin t-Testi” ile araştırılmıştır. Kontrol ve deney gruplarının kendi içinde, problem çözme becerisi ön, son ve izleme testi puan ortalamaları arasında anlamlı düzeyde bir fark olup olmadığg ise "Tekrarlı Ölçümler İçin Tek Faktörlü ANOVA” ile analiz edilmiştir.

Araştırma sürecinin başında kontrol ve deney grubundaki öğrencilerin fen bilimleri dersi akademik başarıları açısından denk olup olmadığını belirlemek amaciyla deney ve kontrol grubundaki öğrencilerin I. dönem fen bilimleri dersi karne notları istatistiki olarak karşılaştırılmıştır. Buna ilaveten deneysel işlemin başlangıcında kontrol ve deney grubundaki öğrencilerin, problem çözme beceri seviyeleri açısından da denklikleri karşılaştırılmış ve sonuçları aşağıda verilmiştir. Ölçekten alınan toplam puan, ölçekteki madde sayısına bölünerek, her bir öğrenci için problem çözme beceri puanı hesaplanmıştır.

Tablo 3. Kontrol ve deney grubundaki öğrencilerin 6. sınıf 1. dönem fen bilimleri dersi akademik başarı not ortalamalarına ilişkin bağımsız gruplar için t-testi sonuçları

\begin{tabular}{ccccccc}
\hline Grup & $\mathbf{N}$ & $\overline{\mathbf{x}}$ & $\mathbf{S}$ & $\mathbf{s d}$ & $\mathbf{t}$ & $\mathbf{p}$ \\
\hline Kontrol & 45 & 79,20 & 12,89 & 89 & 0,09 & $\mathbf{9 3}$ \\
Deney & 46 & 78,96 & 13,87 & & & \\
\hline
\end{tabular}

Tablo 3 incelendiğinde kontrol $(\overline{\mathrm{x}}=79,20)$ ve deney $(\overline{\mathrm{x}}=78,96)$ grubunda bulunan öğrencilerin 6 . sınıf akademik başarı not ortalamaları arasında anlamlı düzeyde bir farklılık olmadığ görülmektedir $\left(t_{(89)}=0,09 ; p>.05\right)$. Bu bulguya göre, araştırmanın başında kontrol ve deney grubunda yer alan öğrencilerin başarı açısından benzer düzeyde ve denk olduğu söylenebilir.

Tablo 4. Kontrol ve deney grubundaki öğrencilerin problem çözme becerisi ön test puanlarına ilişkin bağımsız gruplar için t-testi sonuçları

\begin{tabular}{lllllll}
\hline Grup & $\mathbf{N}$ & $\overline{\mathrm{x}}$ & $\mathbf{S}$ & sd & $\mathbf{t}$ & $\mathbf{p}$ \\
\hline
\end{tabular}




\begin{tabular}{ccccccc}
\hline Kontrol & 45 & 3,30 & 0,50 & 89 & 0,12 &, 91 \\
Deney & 46 & 3,29 & 0,44 & & & \\
\hline
\end{tabular}

Tablo 4'e göre, araştırma sürecinin başında kontrol $(\overline{\mathrm{x}}=3,30)$ ve deney $(\overline{\mathrm{x}}=3,29)$ grubunda bulunan öğrencilerin, problem çözme becerisi ön test puanları arasında anlamlı düzeyde bir farklılı yoktur $\left(t_{(89)}=0,12 ; p>, 05\right)$. Bu bulgu, araştırmanın başında kontrol ve deney grubunda bulunan öğrencilerin problem çözme beceri seviyelerinin benzer olduğunu göstermektedir.

Tablo 5. Kontrol ve deney grubundaki öğrencilerin problem çözme becerisi son test puanlarına ilişkin bağımsız gruplar için t-testi sonuçları

\begin{tabular}{ccccccc}
\hline Grup & $\mathbf{N}$ & $\overline{\mathrm{x}}$ & $\mathbf{S}$ & $\mathbf{s d}$ & $\mathbf{t}$ & $\mathbf{p}$ \\
\hline Kontrol & 45 & 3,36 & 0,51 & & & \\
Deney & 46 & 3,80 & 0,47 & & $-4,27$ & $\mathbf{0 0}$ \\
\hline
\end{tabular}

Tablo 5'teki bulgular, araştırmanın sonunda kontrol ve deney grubundaki öğrencilerin, problem çözme becerisi son test puanları arasında anlamlı düzeyde bir farkın olduğunu göstermektedir $\left(t_{(89)}=-4,27 ; p<, 05\right)$. Kontrol $(\overline{\mathrm{x}}=3,36)$ ve deney $(\overline{\mathrm{x}}=3,80)$ grubunun problem çözme becerisi aritmetik ortalamaları incelendiğinde, deney grubundaki öğrencilerin puanlarının kontrol grubundaki öğrencilere göre anlamlı düzeyde daha yüksek olduğu görülmektedir.

Tablo 6. Kontrol ve deney grubundaki öğrencilerin problem çözme becerisi izleme testi puanlarına ilişkin bağımsız gruplar için t-testi sonuçları.

\begin{tabular}{ccccccc}
\hline Grup & $\mathbf{N}$ & $\overline{\mathrm{x}}$ & $\mathbf{S}$ & $\mathbf{s d}$ & $\mathbf{t}$ & $\mathbf{p}$ \\
\hline Kontrol & 45 & 3,30 & 0,45 & 89 & $-4,42$ & $\mathbf{, 0 0}$ \\
Deney & 46 & 3,73 & 0,48 & & & \\
\hline
\end{tabular}

Tablo 6'daki bulgulara göre kontrol $(\overline{\mathrm{x}}=3,30)$ ve deney $(\overline{\mathrm{x}}=3,73)$ grubundaki öğrencilerin araştırma tamamlandıktan üç ay sonrasındaki problem çözme beceri puanları arasında anlamlı seviyede bir fark vardır ve bu fark deney grubu lehinedir $\left(t_{(89)}=-4,42 ; p<, 05\right)$. Başka bir ifadeyle, deney grubundaki öğrencilerin araştırmanın uygulama basamağı tamamlandıktan üç ay sonrasındaki problem çözme beceri puanları, kontrol grubundaki öğrencilere kıyasla anlamlı düzeyde daha yüksektir. 
Tablo 7. Kontrol grubundaki öğrencilerin problem çözme becerisi ön test, son test ve izleme testi puanlarına ilişkin merkezi eğilim ve yayılma ölçüleri

\begin{tabular}{ccccc}
\hline Ölçüm No & Ölçüm & $\mathbf{N}$ & $\overline{\mathbf{x}}$ & $\mathbf{S}$ \\
\hline $\mathbf{1}$ & Öntest & 45 & 3,30 & 0,50 \\
$\mathbf{2}$ & Sontest & 45 & 3,36 & 0,51 \\
$\mathbf{3}$ & İzleme Testi & 45 & 3,30 & 0,45 \\
\hline
\end{tabular}

Tablo 8. Kontrol grubundaki öğrencilerin problem çözme becerisi ön test, son test ve izleme testi puanlarına ilişkin tekrarlı ölçümler için tek faktörlü ANOVA sonuçları

\begin{tabular}{crrcrrr}
\hline $\begin{array}{c}\text { Varyansın } \\
\text { Kaynağı }\end{array}$ & $\begin{array}{c}\text { Kareler } \\
\text { Toplamı }\end{array}$ & sd & $\begin{array}{c}\text { Kareler } \\
\text { Ortalaması }\end{array}$ & F & p & $\begin{array}{c}\text { Anlamlı } \\
\text { Fark }\end{array}$ \\
\hline Denekler arası & 4,06 & 44 & 0,09 & & & \\
Ölçüm & $\mathbf{0 , 0 9}$ & $\mathbf{2}$ & $\mathbf{0 , 0 5}$ & $\mathbf{0 , 1 5}$ & $\mathbf{, 8 6}$ & Yok \\
Hata & 27,11 & 88 & 0,31 & & & \\
Toplam & 31,26 & 134 & & & & \\
\hline
\end{tabular}

Tablo 7 incelendiğinde kontrol grubunda bulunan öğrencilerin, problem çözme becerisi son test $(\overline{\mathrm{x}}=3,36)$ puan ortalaması ön test $(\overline{\mathrm{x}}=3,30)$ ve izleme testi puan ortalamasından $(\overline{\mathrm{x}}=3,30)$ daha yüksektir. Ancak Tablo 8 'deki bulgular, ön test, son test ve izleme testi puanları arasındaki farkın anlamlı düzeyde olmadığını göstermektedir $\left(F_{(2-88)}=0,15 ; p>, 05\right)$. Buna göre kontrol grubundaki öğrencilerin araştırmanın başındaki, sonundaki ve uygulama basamağı tamamlandıktan üç ay sonrasındaki problem çözme beceri düzeylerinin benzer olduğu söylenebilir.

Tablo 9. Deney grubundaki öğrencilerin problem çözme becerisi ön test,

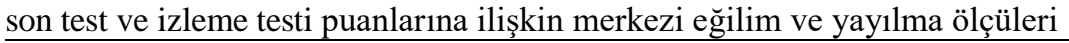

\begin{tabular}{ccccc}
\hline Ölçüm No & Ölçüm & $\mathbf{N}$ & $\overline{\mathbf{x}}$ & $\mathbf{S}$ \\
\hline $\mathbf{1}$ & Öntest & 46 & 3,29 & 0,44 \\
$\mathbf{2}$ & Sontest & 46 & 3,80 & 0,47 \\
$\mathbf{3}$ & İzleme Testi & 46 & 3,73 & 0,48 \\
\hline
\end{tabular}


Tablo 10. Deney grubundaki öğrencilerin problem çözme becerisi ön test, son test ve izleme testi puanlarına ilişkin tekrarlı ölçümler için tek faktörlü ANOVA sonuçları

\begin{tabular}{crrrrrr}
\hline $\begin{array}{c}\text { Varyansın } \\
\text { Kaynağı }\end{array}$ & $\begin{array}{c}\text { Kareler } \\
\text { Toplamı }\end{array}$ & sd & $\begin{array}{c}\text { Kareler } \\
\text { Ortalaması }\end{array}$ & F & p & $\begin{array}{c}\text { Anlamlı } \\
\text { Fark }\end{array}$ \\
\hline Denekler arası & 28,13 & 45 & 0,63 & & & \\
Ölçüm & $\mathbf{6 , 9 1}$ & $\mathbf{2}$ & $\mathbf{3 , 4 6}$ & & & $\mathbf{1 - 2}$ \\
Hata & 1,41 & 90 & 0,02 & & $\mathbf{2 2 0}, \mathbf{0 0}$ & $\mathbf{1 - 3}$ \\
Toplam & 36,45 & 137 & & & & \\
\hline
\end{tabular}

Tablo 9 ve 10'a göre, deney grubunda yer alan öğrencilerin problem çözme becerisi ön test $(\overline{\mathrm{X}}=3,29)$, son test $(\overline{\mathrm{X}}=3,80)$ ve izleme testi $(\overline{\mathrm{X}}=3,73)$ puanlar1 arasında anlamlı düzeyde bir fark vardır $\left(F_{(2-90)}=220,82 ; p<, 05\right)$. Tablo 10 incelendiğinde bu anlamlı farkın ön test ile son test puan ortalamaları arasında, son test lehine ve izleme testi puan ortalaması ile ön test puan ortalaması arasında, izleme testi lehine olduğu görülmektedir. Bu bulgu deney grubundaki öğrencilerin araştırmanın sonundaki ve araştırma sona erdikten üç ay sonrasındaki problem çözme beceri düzeylerinin, araştırmanın başındakine göre anlamlı seviyede daha yüksek olduğunu göstermektedir. Buna ilaveten, deneysel işlem sona erdikten üç ay sonrasındaki problem çözme becerisi puan ortalaması (izleme testi), son test puan ortalamasından düşük olmasına rağmen, izleme testi puan ortalaması ile son test puan ortalaması arasındaki farkın anlamlı olmadığı Tablo 10'da görülmektedir. Bir başka ifadeyle, deney grubu öğrencilerinin araştırmanın sonundaki ve araştırma tamamlandıktan üç ay sonrasındaki problem çözme beceri düzeylerinin benzer olduğu söylenebilir.

\subsection{Tartışma}

\section{TARTIŞMA ve SONUÇ}

$\mathrm{Bu}$ araştırma bilim şenliklerinin ortaokul altıncı sınıf öğrencilerinin problem çözme beceri seviyeleri üzerine etkisini incelemek amacıyla yapılmıştır. Araştırma sürecinin başında kontrol ve deney grubundaki öğrenciler, fen bilimleri dersi akademik başarıları açısından benzer düzeyde ve denktir $\left(t_{(89)}=0,09 ; p>, 05\right)$. $\mathrm{Bu}$ durum, deney ve kontrol grubundaki öğrencilerin problem çözme becerileri üzerinde deneysel işlemin etkisinin karşılaştırılabilmesi için önemli ve uygun bir sonuçtur. Ayrıca araştırmanın başında kontrol ve deney grubundaki öğrencilerin problem çözme beceri seviyeleri benzerdir $\left(t_{(89)}=0,12 ; p>, 05\right)$. Bu sonuç, deneysel işlemin kontrol ve deney grubundaki öğrencilerin problem çözme becerisi üzerindeki etkisinin karşılaştırılabilmesi amacına uygundur.

Araştırmanın sonunda deney grubundaki öğrencilerin problem çözme beceri puanlarının, kontrol grubundaki öğrencilere göre anlamlı düzeyde daha yüksek olduğu belirlenmiştir $\left(t_{(89)}=-4,27 ; p<, 05\right)$. Araştırma tamamlandıktan üç ay sonra da deney grubundaki öğrencilerin problem çözme beceri puanları, kontrol grubundaki öğrencilere kıyasla anlamlı düzeyde daha yüksektir $\left(t_{(89)}=\right.$ $4,42 ; p<, 05)$. Buna göre, bilim şenliklerinin kontrol grubunda gerçekleştirilen öğretime kıyasla, ortaokul altıncı sınıf öğrencilerinin problem çözme beceri 
düzeylerini arttırmada ve problem çözme becerisinde meydana gelen gelişimin üç aylık bir süre sonunda da korunmasını sağlamada daha etkili olduğu söylenebilir.

Kontrol grubundaki öğrencilerin araştırmanın başındaki, sonundaki ve araştırma sona erdikten üç aylık süre sonundaki problem çözme becerileri benzer seviyededir $\left(F_{(2-88)}=0,15 ; p>, 05\right)$. Deney grubundaki öğrencilerin ise araştırmanın sonundaki ve araştırma tamamlandıktan üç ay sonrasındaki problem çözme beceri puanları, araştırmanın başındakine göre anlamlı seviyede daha yüksektir. Buna ilaveten deney grubunun araştırmanın sonundaki ve araştırma tamamlandıktan üç ay sonrasındaki problem çözme beceri düzeyleri benzerdir $\left(F_{(2-90)}=220,82 ; p<, 05\right)$. Bu bulgulara dayanarak, bilim şenliklerinin öğrencilerin problem çözme beceri düzeylerini geliştirmede etkili olduğu ve problem çözme beceri düzeyini geliştirme etkisinin üç aylık bir süre sonunda da devam ettiği söylenebilir. Literatür incelendiğinde genellikle bilim şenliklerinin duyuşsal özellikler üzerindeki etkilerinin araştırıldığı görülmektedir. Bilim şenliklerinin de ziyaretçiler için informal öğrenme ortamları olmasına dayanarak, informal öğrenme ortamlarının öğrencilerin bilişsel ve duyuşsal becerilerinin gelişimlerine yönelik literatüre de yer verilmiştir. Örneğin Altıntaş (2014) informal öğrenme ortamının ortaokul 6. sınıf öğrencilerinin doğa ve toprağa yönelik başarılarına ve tutumlarına olan etkisini araştırmak, informal eğitim ortamındaki öğrenme durumlarına ilişkin kişisel algılarını ve ana fikirleri anlama düzeylerini belirlemek amacıyla bir araştırma yapmıştır. Araştırma sonucunda informal öğrenme ortamı olan Toprak Bilim Okulu'nda verilen eğitimin doğa ve toprağa yönelik başarılarında olumlu yönde artış sağladığı ve öğrencilerin informal ortamdaki öğrenme durumlarına ilişkin kişisel algılarının olumlu yönde olduğu sonuçlarına ulaşılmıştır. Ertaş, Şen ve Parmaksızoğlu (2011) yaptığı araştırmada informal öğrenme alanlarının dokuzuncu sınıf öğrencilerinin "enerji” konusunu günlük hayatla ilişkilendirme düzeylerine etkisini incelemiştir. Araştırmada okul dış1 bilimsel etkinliklerin öğrencilerin enerji konusunu anlama ve konuyu günlük hayatla ilişkilendirme düzeylerini olumlu yönde etkilediği sonucuna ulaşılmıştır. Tatar ve Bağrıyanık (2012) tarafından yapılan araştırmada fen bilgisi öğretmenlerinin okul dışı eğitim aktiviteleri ve bu eğitime yönelik görüşleri incelenmiştir. Araştırmada öğretmenlerin büyük çoğunluğunun bu aktiviteleri öğrencilerin yaparak yaşayarak öğrenmeleri için tercih ettikleri ve aktivitelerin öğrencilerin ilgi, istek ve meraklarını attırmada etkili olduğu sonucuna ulaşılmıştır. Çavuş, Umdu Topsakal ve Öztuna Kaplan (2013) tarafindan yapılan araştırmada Kocaeli'nde Bilgievleri'nde gerçekleştirilen faaliyetlerin öğrencilere çevre bilinci kazandırmasına ilişkin öğretmen görüşleri incelenmiştir. Araştırmada okul dışı öğrenme ortamlarının öğrencilerin çevre bilinci kazanmalarında olumlu yönde etkisinin olduğu, bu sebeple okul dışı öğrenme ortamlarının ve bu ortamlarda gerçekleştirilen etkinliklerin sayısının arttırılması gerektiği sonuçlarına ulaşılmıştır. Nadelson ve Jordan (2012) ise yaptığı araştırmada öğrencilerin bir günlük alan gezisi sonrasında tutumlarının olumlu yönde olduğunu belirlemiştir. Knapp (2000) informal öğrenme ortamlarından olan uzun süreli alan gezisi uygulamalarının, öğrencilerin hafızalarındaki etkisini araştırmıştır. Araştırmada uygulama çalışmalarındaki etkinlikler ve sergilerle ilgili olan konularda, ilköğretim öğrencilerinin kalıcı bilgiler edindikleri, yapılan 
uygulamalar ile oldukça fazla deneyim kazandıkları ve uygulanan etkinliklerin sergilerin içerdikleri konulara karşı ilgilerinin de arttığı sonuçlarına ulaşılmıştır. Rapp (2005) yaptığı çalışmasında, informal öğrenme ortamlarından olan uzun süreli ve tekrarlanan müze gezilerinin öğrencilerin derinlemesine öğrenme ve kavramalarına imkan sağladığ 1 sonucuna ulaşmış ve müze gezilerinin çok sık tekrarlanması gerektiğini belirtmiştir. Bozdoğan (2007) bilim ve teknoloji müzelerine yapılan gezilerin öğrencilerin fen konularına karşı ilgi ve akademik başarılarına etkisini incelemiştir. Araştırmada Feza Gürsey Bilim Merkezi'nde ve Enerji Parkı'nda bulunan araç gereçlerin ve burada yapılan etkinliklerin, ilköğretim ikinci kademe öğrencilerinin fen konularına karşı ilgilerini ve akademik başarılarını anlamlı bir şekilde geliştirmede ve devamının sağlanmasında önemli bir etkiye sahip olduğu görülmüştür. Özetle Bozdoğan (2007), Çavuş, Umdu Topsakal ve Öztuna Kaplan (2013), Ertaş, Şen ve Parmaksızoğlu (2011), Knapp (2000), Rapp (2005) yaptıkları araştırmada informal öğrenme ortamlarının öğrencilerin bilişsel becerilerinin gelişimine katkı sağladığı sonucuna ulaşmışlardır. Bilim şenliklerinin de informal öğrenme ortamları olduğu göz önüne alındığında Bozdoğan (2007), Çavuş, Umdu Topsakal ve Öztuna Kaplan (2013), Ertaş, Şen ve Parmaksızoğlu (2011), Knapp (2000), Rapp (2005)'in ulaştığı bu sonuçlar, problem çözme becerisinin de bilişsel bir özellik olması açısından bu araştırmada ulaşılan bilim şenliklerinin problem çözme becerisi gibi bilişsel özellikleri geliştirmede etkili olduğu sonucunu destekler niteliktedir.

Ayrıca bilim şenliklerinin öğrencilerin duyuşsal özelliklerinin gelişimine etkisinin araştırıldığı literatürde yer alan çalışmalarda, bilim şenliklerinin öğrencilerin ilgi, tutum gibi duyuşsal özelliklerin gelişimine olumlu katkı sağladığı sonuçlarına ulaşıldığı görülmektedir. Örneğin Şahin (2012) yaptığ1 çalışmada bilim şenliklerinin 10. sınıf öğrencilerinin kimya alanına yönelik tutumlarına olan etkisini araştırmıştır. Araştırmanın sonucunda bilim şenliklerinin, lise öğrencilerinin kimya dersine yönelik tutumlarının gelişimi üzerinde olumlu etkileri olduğu sonucuna ulaşmıştır. Ayrıca bu araştırmada kimya derslerine ilgisi düşük olan öğrencilerin, bilim şenliklerindeki projeleri yerinde inceleyerek oradaki sunumlara katılımlarının sağlanmasından sonraki aşamada işlenen derslerde daha aktif ve ilgili olduklarının gözlemlendiği belirtilmiştir. Camcı (2012) araştırmasında ilköğretim okullarında bilim şenliği/proje yarışması etkinliklerine katılan ve katılmayan öğrencilerin bilime ve bilim insanlarına yönelik ilgi ve imajları arasında bir farklılık olup olmadığını araştırmıştır. Araştırmada bilim şenliğine katılan öğrencilerin daha çok bilimin doğası ve bilimsel süreçle ilgilenirken, bilim şenliğine katılmayan öğrencilerin daha çok günlük hayatta doğrudan gözlemlenen olaylarla ilgili olduğu ortaya çıkmıştır. Erkek öğrenciler bilime kız ögrencilere oranla daha fazla ilgi gösterirken, bilim insanı imajları karşılaştırıldığında erkek ve kız öğrenciler benzerlik göstermektedir. Karadeniz ve Ata (2013) tarafından yapılan çalışmada Sosyal Bilgiler dersi kapsamında uygulanan Sosyal Bilgiler Proje Fuarına projeleriyle katılan öğrencilerin süreçle ilgili görüşleri incelenmiştir. Araştırmanın sonucunda; öğrencilerin Sosyal Bilgiler Proje Fuarıyla ilgili olarak olumlu görüş ve düşünceler geliştirdikleri belirlenmiştir. Yıldırım ve Şensoy (2014) bilim şenliklerinin 
ortaokul altıncı sınıf öğrencilerinin fen bilimleri dersine yönelik tutumları üzerine etkisini yarı deneysel bir araştırma ile incelemişlerdir. Araştırmanın sonucunda bilim şenliklerinin, ortaokul öğrencilerinin fen dersine yönelik tutumlarının gelişimi ve bu gelişimin korunması üzerinde anlamlı bir etkisi olduğu sonucuna ulaşmıştır. Özetle Camcı (2008), Karadeniz ve Ata (2013), Perry (1995), Şahin (2012) ve Yıldırım ve Şensoy (2014) yaptıkları araştırmalarda bilim şenliklerinin ilgi, tutum gibi duyuşsal özelliklerin gelişimine katkı sağladığı sonuçlarına ulaşmışlardır. Buna ilaveten Bozdoğan (2007), Knapp (2000), Nadelson ve Jordan (2012), Tatar ve Bağrıyanık (2012) tarafından yapılan çalışmalarda informal öğrenme ortamlarının öğrencilerin ilgi ve tutum gibi duyuşsal özelliklerini olumlu yönde geliştirmede etkili olduğu sonuçlarına ulaşılmıştır.

\subsection{Sonuç}

Özetle bu araştırmanın sonucunda bilim şenliklerinin ortaokul altıncı sınıf öğrencilerinin problem çözme beceri düzeylerinin gelişimine anlamlı seviyede katkı sağladığı ve araştırma tamamlandıktan üç ay sonra da bu gelişimin korunduğu görülmüştür. Ancak kontrol grubundaki öğrencilerin problem çözme beceri düzeyinde anlamlı seviyede bir değişimin gerçekleşmediği belirlenmiştir. Ayrıca araştırmanın başında kontrol ve deney grubu öğrencilerinin problem çözme becerileri benzer düzeydeyken, araştırmanın sonunda ve araştırma tamamlandıktan üç ay sonra deney grubundaki öğrencilerin problem çözme becerileri kontrol grubu öğrencilerinden anlamlı seviyede daha yüksektir. $\mathrm{Bu}$ sonuçlar öğrencilerin problem çözme beceri düzeylerini geliştirmede ve bu gelişimin korunmasını sağlamada bilim şenliklerinin anlamlı seviyede etkili olduğunu, kontrol grubunda uygulanan öğretimin ise etkili olamadığını göstermektedir.

$\mathrm{Bu}$ sonucun temel nedeni bilim şenliklerinde öğrencilerin aktif olarak yer almaları, bilimsel araştırma sürecine uygulamalı olarak doğrudan katılmaları ve bir bilim insanı gibi çalışarak bir probleme çözüm bulma veya ürün ortaya koyma heyecanını yaşamaları ile açıklanabilir. Bu bağlamda fen öğretimi sürecinde bilim şenliklerinin kullanılmasının, etkili öğrenme ürün ve sonuçlarının ortaya çıkmasına katkı sağlayabileceği söylenebilir. Bilim şenliklerinin problem çözme beceri düzeyleri üzerindeki olumlu etkisi göz önüne alındığında, ülkemizdeki okullarda bilim şenlikleri gibi etkinliklerin yaygınlaştırılması ve öğrencilerin bu tür etkinliklere katılımlarının teşvik edilmesi gerektiği düşünülmektedir.

Ayrıca araştırmanın sonucuna dayanarak ve ziyaretçiler için bilim şenliklerinin bir informal öğrenme ortamı olduğu göz önüne alındığında, problem çözme becerisi gibi öğrenme çıktılarının düzeylerini geliştirmede öğrenme öğretme sürecinde bilim şenlikleri gibi informal öğrenme ortamlarına da yer verilmesi, formal öğrenme ortamlarının informal öğrenme ortamlarıyla desteklenmesi gerektiği söylenebilir. Böylece Ortaokul Fen Bilimleri Dersi Öğretim Programında belirtilen informal öğrenme ortamlarından faydalanılması ve öğretim programında vurgulanan problem çözme beceri düzeylerinin geliştirilmesi amaçlarına ulaşılabilir. Stocklmayer, Rennie ve Gilbert (2010) tarafından yapılan araştırmada da, etkili bir fen eğitiminin sunulması için formal 
ve informal eğitim arasındaki bütünleyici durumun genişletilmesi gerektiği belirtilmiştir.

Öğrenme - öğretme sürecini zenginleştirmek, formal öğrenme ortamlarını informal öğrenme ortamlarıyla desteklemek, problem çözme ve bilimsel süreç becerileri gibi bilişsel becerileri geliştirmek, tutum, motivasyon ve ilgi gibi duyuşsal becerileri geliştirmek amacıyla öğrenme - öğretme sürecinde bilim şenlikleri, proje yarışmaları, buluş şenlikleri, bilim - teknoloji müzeleri, hayvanat bahçeleri ve doğa gezileri gibi informal öğrenme ortamlarına da yer verilmesi gerektiği düşünülmektedir. Buna ilaveten bilim şenliklerine etkinlik - proje ile katılan öğrencilerin yanı sıra, etkinlik - proje ile katılmayan öğrenciler de proje değerlendirme, jüri, bilim şenlikleri alanında rehber vb. görev - etkinliklerle bu sürece dahil edilerek, bilim şenliklerine katılmalarının teşvik edilmesi gerektiği önerilebilir. 


\section{KAYNAKLAR}

Altıntaş, F. (2014). Doğa ve topră̆a yönelik hazırlanan informal ögrenme ortamının ilköğretim ögrencileri üzerine etkileri. Yayınlanmamış yüksek lisans tezi, Hacettepe Üniversitesi Eğitim Bilimleri Enstitüsü, Ankara.

Aslan, A. E. (2002). Örgütte Kişisel Gelişim. Ankara: Nobel Yayıncılık.

Baykul, Y. ve Güzeller, C. O. (2014). Sosyal Bilimler için İstatistik (SPSS Uygulamall). Ankara: Pegem A Yayıncılık.

Bozdoğan, A. E. (2007). Bilim ve teknoloji müzelerinin fen öğretimindeki yeri ve önemi. Yayınlanmamış doktora tezi, Gazi Üniversitesi Eğitim Bilimleri Enstitüsü, Ankara.

Bunderson, E. D. ve Anderson, T. (1996). Preservice elementary teachers' attitudes toward their past experience with science fairs. School Science and Mathematics, 96 (7), 371-377.

Büyüköztürk, Ş. (2016). Sosyal bilimler için veri analizi el kitabl, istatistik, araştırma deseni, SPSS uygulamaları ve yorum (22. Baskı). Ankara: Pegem A Yayıncılık.

Büyüköztürk, Ş., Kılı̨̧ Çakmak E., Akgün, Ö. E., Karadeniz, Ş. ve Demirel, F. (2016). Bilimsel araştırma yöntemleri (20. Baskl). Ankara: Pegem A Yayınc1lik.

Camc1 S. 2008. Bilim şenliğine katılan ve katılmayan ögrrencilerin bilim ve bilim insanlarına yönelik ilgi ve imajlarının karşılaş̧ırılması. Yayınlanmamış Yüksek Lisans Tezi, Hacettepe Üniversitesi Sosyal Bilimler Enstitüsü, Ankara.

Çavuş, R., Umdu-Topsakal, Ü. ve Öztuna-Kaplan, A. (2013). İnformal öğrenme ortamlarının çevre bilinci kazandırmasına ilişkin öğretmen görüşleri: Kocaeli bilgi evi örneği. Pegem Eğitim ve Öğretim Dergisi, 3 (1), 15-26.

Ertaş, H., Şen, A.İ. ve Parmaksızoğlu, A. (2011). Okul dışı bilimsel etkinliklerin 9. sınıf enerji konusunu günlük hayatla ilişkilendirme düzeyine etkisi. Necatibey Ĕgitim Fakültesi, Elektronik Fen ve Matematik Eğitimi Dergisi, 5 (2), 178-198.

Hofstein, A. ve Rosenfeld, S. (1996). Bridging the gap between formal and informal science learning. Studies in Science Education, 28, 87-112.

Kalaycı, N. (2001). Sosyal bilgilerde problem çözme ve uygulamalar. Ankara: Gazi Kitabevi.

Kalaycı, Ş. (2016). SPSS uygulamalı çok değişkenli istatistik teknikleri. (7. baskı). Ankara: Asil Yayın Dağıtım.

Karadeniz, O. ve Ata, B. (2013). Sosyal bilgiler dersinde proje fuarının kullanılmasına ilişkin öğrenci görüşleri. Adıyaman Üniversitesi Sosyal Bilimler Enstitüsü Dergisi, Sosyal Bilgiler Öğretimi Özel Saylsı, 6 (14), 375-410.

Knapp, D. (2000). Memorable experiences of a science field trip. School Science and Mathematics. 100 (2), 65-72. 
Kneeland, S. (Çev: Kalaycı, Nurdan) (2001). Problem çözme. Ankara: Gazi Kitabevi.

Korkmaz, H. (2004). The images of the scientist through the eyes of the Turkish children. Panhandle Science ve Mathematics Conference, Canyon, Texas, USA, 25 September 2004.

Köklü, N., Büyüköztürk, Ş. ve Çokluk Bökeoğlu, Ö. (2006). Sosyal bilimler için istatistik. Ankara: Pegem A Yayıncılık.

Linn, R. L. ve Gronlund, N. E. (2000). Measurement and assessment in teaching. ( $8^{\text {th }}$ Edition). New Jersey, USA: Prentice Hall.

MEB, (2006). Illkögrretim fen ve teknoloji dersi (6, 7 ve 8. siniflar) öğretim $\begin{array}{llll}\text { programi. } & 10 & \text { Nisan } & 2016\end{array}$ http://ttkb.meb.gov.tr/program2.aspx?islem $=1 \& \mathrm{kno}=25 \quad$ adresinden erişilmiştir.

MEB, (2013). Illköğretim kurumlarl fen bilimleri dersi (3, 4, 5, 6, 7 ve 8. Sinıflar)

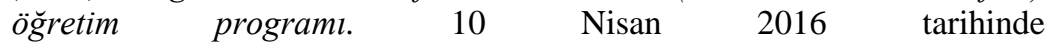
http://ttkb.meb.gov.tr/www/guncellenen-ogretim-programlari/icerik/151 adresinden erişilmiştir.

Nadelson, L.S. ve Jordan, R.J. (2012). Student's attitudes toward a recall of outside day: An environmental science field trip. The Journal of Research, 105, 220- 231.

Perry, P. J. (1995). Getting started in science fairs: From planning to judging. Blue Ridge Summit, PA: TAB Books.

Rapp, W. (2005). Inquiry-based environments for the inclusion of students with exceptional learning needs. Remedial and Special Education. 26 (5), 297310.

Senemoğlu, N. (2001). Gelişim, ögrenme ve öğretim, kuramdan uygulamaya. Ankara: Gazi Kitabevi.

Sim, J. ve Wright, C. (2002). Research in health care: Concepts, designs and methods. United Kingdom, Cheltenham: Nelson Thornes Ltd.

Stocklmayer, S.M., Rennie, L.J. ve Gilbert, J.K. (2010). The roles of the formal and informal sectors in the provision of effective science education. Studies in Science Education, 46 (1), 1-44.

Şahin, Ş. (2012). Bilim şenliklerinin 10. sınıf öğrencilerinin kimya dersine yönelik tutumlarına olan etkisi. Uşak Üniversitesi Sosyal Bilimler Dergisi, 5 (1), 89-103.

Tatar, N. ve Bağrıyanık, K.E. (2012). Opinions of science and technology teachers about outdoor education. Ilkögretim Online, 11 (4), 883-896.

Tabachnick, B. G. ve Fidell, L. S. (2013).Using multivariate statistics. $\left(6^{\text {th }}\right.$ edition). Boston: Pearson.

Türkmen, H. (2010). İnformal (sınıf-dış1) fen bilgisi eğitimine tarihsel bakış ve eğitimimize entegrasyonu. Çukurova Üniversitesi Ĕ̆itim Fakültesi Dergisi, 3 (39), 46-59. 
Yaman, S. (2003). Fen bilgisi ĕgitiminde probleme dayall öğrenmenin ögrenme ürünlerine etkisi. Yayınlanmamış doktora tezi. Gazi Üniversitesi Eğitim Bilimleri Enstitüsü, Ankara.

Yıldırım, H.İ. ve Şensoy, Ö. (2014). Bilim şenliklerinin ortaokul 6. sınıf öğrencilerinin fen bilimleri dersine yönelik tutumlarına etkisi. 11. Ulusal Fen Bilimleri ve Matematik Ĕgitimi Kongresi, 822-823. 11-14 Eylül, 2014, Adana: Çukurova Üniversitesi.

Yıldırım, H.İ. (2009). Eleştirel düşünmeye dayalı fen ĕğitiminin öğrenme ürünlerine etkisi. Yayınlanmamış doktora tezi. Gazi Üniversitesi Eğitim Bilimleri Enstitüsü, Ankara.

Young, T. E. (2000). Science Fair Projects Bring it All Together. Book Report, March/ April, 6-8. 


\section{Introduction}

\section{EXTENDED ABSTRACT}

This study has been conducted for the purpose of studying the effect of science fairs on the $6^{\text {th }}$ grade secondary school students' problem solving skills.

\section{Method}

A quasi-experimental method and an experimental pattern with control and experiment groups are used in the research. The sampling of the study consisted of the year 6 students studying in a public secondary school located in Ankara during the $2^{\text {nd }}$ semester of the academic year 2014-2015.

A "Problem Solving Skills Scale" was employed in order to determine the problem solving skill levels of the $6^{\text {th }}$ grade students. Having been prepared in the 5 likert type ranging between "I fully agree" to "I do not agree at all". The Cronbach Alpha $(\alpha)$ reliability coefficient of the scale was calculated as 0,88 . In analyzing the data obtained through the application of the Problem Solving Skills Scale, each positive statement included items has been rated in the following manner: "I fully agree" 5 points, "I agree" 4 points, "I partially agree" 3 points, "I do not agree" 2 points, and "I do not agree at all" 1 point. Negative statements were coded inversly. The total score obtained from the scale was divided into the number of items included in the scale and a problem solving skill score was calculated for each student. This way, the lowest score in the scale was 1 , while the highest was 5 .

During this study, the following tools were used: A Problem Solving Skills Scale, a pre test for identifying the a problem solving skill levels of the $6^{\text {th }}$ grade students at the beginning of the study, a post test for identifying the effect of the experimental process at the end of the study, and a monitoring test for following up on the results of the study 3 months after the study. A statistically significant increase in that score means a positive improvement on the problem solving skill level.

The study was conducted on the grade 6 students studying in a secondary school located in Ankara during the $2^{\text {nd }}$ semester of the academic year 2014-2015. Two control groups and two experimental groups were randomly selected from the year 6 classes. A total of 91 students, 45 in the control group and 46 in the experimental group, constituted the study sample. Science lessons were taught by the same science teacher to both the control and experimental groups. No experimental procedure was applied to the control group. The year 6 Science Courses was conducted in line with the existing curriculum and in a student oriented manner for the control group students.

A Similar training was implemented in the experimental and control group. But in the experimental group, 15 to 20 minutes of 1 course was devoted to science fair activities each week. The experimental group students were informed as to the science fairs, scientific methods, project-research steps, project journals through presentations and presented with case studies conducted regarding the said matters. The students were divided into groups of 2-3 and asked to come up with a scientific problem of their choice for the science fair and conduct a study on the solution of their respective problems. Of the activities designed for the solution of the designated problems based on the knowledge gathered as a result of the studies conducted by the students, those found consistent with the secondary school level were chosen by the teacher by taking into consideration the Academic Curriculum of the Science Course and thus a science fair was prepared by the students. The students prepared posters and presentations for such activities under the guidance of the teacher. As a result of the 15 weeks preparation period, the science fair was opened and the students presented their activities to the visitors for two days. 
Independent Samples t-test analysis was performed in order to identify a statistically significant difference between the average scores of the control and experimental groups. One-Way ANOVA for Repeated Measures was conducted in order to identify a statistically significant difference between the average scores of the control and experimental group students obtained from the pre test at the beginning of the study and the post test at the end of the study and the monitoring test three months after the study.

\section{Result and Discussion}

The academic achievement levels of the students in the control and experimental groups were more or less similar and equal at the beginning of the study. Moreover, the problem solving skill levels of the students in the control and experimental groups were similar at the beginning of the study as well. Such results are important and applicable in terms of comparing the respective effects of science fairs and curriculum based student centric education program on the problem solving skill. As a result of the study, it was observed that the problem solving skill levels of the students in the experimental group where science fair was conducted increased significantly and such increase in the problem solving skill levels was also maintained for 3 months after the study. However, no statistically significant difference was noted in the problem solving skill levels of the control group during the academic process. Moreover, while the problem solving skills of the students in the control and experimental groups were more or less at the same level, the problem solving skill levels of the students in the experimental group were found to be significantly higher than that of the students in the control group at the end of the study and 3 months thereafter. Such results show that the science fairs are significantly effective in terms of improving the problem solving skill levels of the students and ensuring their permanency and that the education applied to the control group was not effective.

The main reason for such a result can be explained by the fact that the students actively have participated in the science fairs, directly involved in the practical research process and experienced the joy and excitement of coming up with a solution to a problem or presenting a product by working like a scientist. In this respect, it can be argued that the implementation of science fairs in teaching science lessons may contribute to effective learning and academic outcomes. It is believed that the events such as science fairs should be extended to more schools in our country and students encouraged to participate in such events. Based on the results of the study it can be suggested that informal learning environments such as science fairs should also be included as part of the learning process. In this way, the objectives set for benefiting from informal learning environments mentioned in the Science Course Curriculum can be realized. 